\title{
The Labour Party \\ SINCE 1945
}




\title{
THE LABOUR PARTY SINCE 1945
}

\author{
KEVIN JEFFERYS
}

Macmillan Education 
ISBN 978-0-333-52975-1 ISBN 978-1-349-22902-4 (eBook)

DOI $10.1007 / 978-1-349-22902-4$

(C) Kevin Jefferys 1993

Softcover reprint of the hardcover 1st edition 1993

All rights reserved. For information, write:

Scholarly and Reference Division,

St. Martin's Press, Inc., 175 Fifth Avenue,

New York, N.Y. 10010

First published in the United States of America in 1993

ISBN 978-0-312-09624-3

Library of Congress Cataloging-in-Publication Data

Jefferys, Kevin.

The Labour Party since 1945 / Kevin Jefferys.

p. $\mathrm{cm}$.

Includes bibliographical references and index.

ISBN 978-0-312-09624-3

1. Labour Party (Great Britain) 2. Great Britain-Politics and government-1945- I. Title.

JN1129.L35J44 1993

324.24107-dc20

93-6701

CIP 
For Peter and Joy 


\section{Contents}

Introduction

1 Labour's Finest Hour, 1945-51

2 Years of Opposition, 1951-64

3 The Wilson Governments, 1964-70

4 'Crisis. What Crisis?', 1970-79

5 The End of the Road?, 1979-92

Conclusion

Notes

Select Bibliography

Index 